\title{
Self-Study Methodology: An Emerging Approach for Practitioner Research in Europe
}

\author{
Mieke Lunenberg, Ann MacPhail, Elizabeth White, Joy Jarvis, Mary O'Sullivan and Hafdís \\ Guđjónsdóttir
}

M. Lunenberg, corresponding author, VU University Amsterdam, Amsterdam, The Netherlands. mieke@lunenberg.info

A. MacPhail, University of Limerick, Limerick, Ireland. Ann.MacPhail@ul.ie

E.White, University of Hertfordshire, Hatfield, England. e.j.white@herts.ac.uk

J. Javis, University of Hertfordshire, Hatfield, England. j.jarvis@herts.ac.uk

M. O'Sullivan, University of Limerick, Limerick, Ireland. Mary.OSullivan@ul.ie

H. Guðjónsdóttir, University of Iceland, Reykjavik, Iceland. hafdgud@hi.is

\begin{abstract}
This chapter highlights the European contribution to the growing knowledge about self-study methodology. Europe is a patchwork of countries, cultures and languages. Looking at teacher educators in Europe, we see a broad variation in background, tasks and opportunities for professional development and self-study research.

In this chapter we firstly map the development of self-study research in Europe which has mainly been the work of individuals and small groups. Then we focus on four countries that are in the forefront: England, Iceland, Ireland and the Netherlands. In all four countries self-study has proved to be a useful and stimulating way to aid the transition from being a teacher - or researcher - to becoming a teacher educator. Self-study methodology not only supported the understanding and development of the teacher education practice, but also led to identity development. Most helpful proved to be working together and mentoring, and sharing results publicly. In this context the role of the biannual S-STEP Castle Conference in England, which offers European self-study researchers to connect with colleagues from North America and Australia, plays an important role.
\end{abstract}

Key-words: Europe, Professional development, Collaboration, Going public

\section{Introduction}

The aim of this chapter is to offer insight into the positioning and development of self-study research in Europe. We will also demonstrate the contribution of self-study research to the professional development of European teacher educators and to the international knowledge base of teacher educators. Based on our findings we will reflect on the further development of selfstudy research in Europe.

\section{Europe}

When we discussed the possible contribution of this chapter to the Handbook, we were conscious that this would not be an easy task. In 2017, when we started to work on this chapter, Europe counted 51 countries. The 28 member countries of the European Union have taken steps to 
increase the compatibility of the higher education system ${ }^{1}$, for example by using the same bachelor-master system, and to support student and teacher exchanges. However, the social, economic, cultural and language differences among the EU countries are still considerable, and even greater when we take all European countries into account. For example, Europe has more than 100 national and regional official languages ${ }^{2}$. Although half of the Europeans are able to have a conversation in a second language, mostly in English ${ }^{3}$, this does not mean - as we will see later in this chapter - that it is self-evident for European teacher educators outside the United Kingdom to connect with English self-study literature from countries where self-study research is wide spread (Australia, New Zealand, and the USA).

\section{Teacher educators' backgrounds}

The backgrounds and professional interests of teacher educators in Europe vary across countries. A study among more than 1000 teacher educators in six European countries (Belgium - the Dutch speaking part called Flanders, England, Ireland, Netherlands, Norway, Scotland) shows for example that most teacher educators in these countries have a master degree, but in the Netherlands, England and Scotland there is still a minority of teacher educators with only a bachelor degree. Moreover, in the Netherlands, England and Flanders teacher educators with a Ph.D. are relatively scarce. In Scotland 95\% of the teacher educators have teaching experience, while in Flanders only $59 \%$ of the teacher educators have been school teachers (Czerniawski, Guberman, \& MacPhail, 2017; InFo-TED, 2016;). The study also measured the academic and educational interest of teacher educators. Academic interest comprised activities characteristic of research universities (e.g. reviewing papers and presenting at conferences) and educational interest comprised activities and content areas specific to teaching and teacher education (e.g. curriculum development and assessment). Significant differences among the six countries were found. Preferences for professional development activities aligned with academic interest were higher among Norwegian and English teacher educators and lower for Dutch and Flemish educators.

Preferences for professional development activities aligned with educational interest were higher among Flemish and Dutch teacher educators and lower among English, Irish and Scottish teacher educators. In Iceland, since 2008, to qualify for a position as a teacher educator a Ph.D. degree is required, whereas before this a master degree was the benchmark. Still, many Icelandic teacher educators do not think of themselves as researchers and there is lack of consensus about the importance of being research active. However, the employment duties of teacher educators, professors, lecturers and senior lecturers, are generally divided into $48 \%$ teaching, $40 \%$ research and $12 \%$ administration. This means that all Icelandic teacher educators are required to conduct research as well as to teach student teachers.

Given these differences in a small sample of European countries, one has to conclude that the background of teacher educators in Europe varies broadly.

\section{Professional development of teacher educators}

The development of self-study research in Europe has to be viewed in the context of increasing attention on teacher educators' professional development which started in the beginning of this century. In 2001 the Dutch Association for Teacher Educators (VELON) established a Professional Standard for Teacher Educators and provided the possibility to become registered as an experienced teacher educator (Koster \& Dengerink, 2001). A programme for teacher educators,

\footnotetext{
${ }^{1}$ See: http://ec.europa.eu/education/policy/higher-education_en

${ }^{2}$ See: https://en.wikipedia.org/wiki/Languages_of_Europe

${ }^{3}$ See: http://ec.europa.eu/education/policy/higher-education/bologna-process_en and https://en.wikipedia.org/wiki/Languages_of_Europe
} 
focusing on the pedagogy of teacher educators and practitioner research, followed (Boei, et al, 2015). In 2004 the Association of Teacher Educators in Europe (ATEE) established a Research and Development Community (comparable with a Special Interest Group) called Professional Development of Teacher Educators. In 2007 a brochure, initiated by UK universities and colleges, Becoming a Teacher Educator: Guidelines for the induction of newly appointed lecturers in Initial Teacher Education, was published (Boyd, Harris, \& Murray), and in 2012 the Flemish Association for Teacher Educators (VELOV) presented a Development Profile for Teacher Educators ${ }^{4}$. Flanders also offers master classes for teacher educators (Tack, 2017). The Hungarian Association for Teacher educators has established a Teacher Educators' Academy that also offers professional development activities ${ }^{5}$. Interestingly, from the point of view of research engagement, Norway concentrated on the researcherly development of teacher educators by establishing NAFOL, a national Norwegian National Research School in Teacher Education, that supports teacher educators in writing their Ph.D. thesis (Lunenberg, Murray, Smith, \& Vanderlinde, 2017). Additionally, the European Commission (EC, 2013) mentions Austria, Estonia, Finland, Germany, Luxembourg, and Sweden as countries where there is some focus on the professional development of teacher educators. This kaleidoscope of activities shows that the context for selfstudy research in Europe varies widely.

From a policy point of view, the European Commission publication Supporting Teacher Educators for Better Learning in 2013 was a milestone. For the first time in history European governors of 28 countries recognized the important role of teacher educators in the educational system. Supporting Teacher Educators for Better Learning Outcomes identifies the centrality of wellprepared and well-supported teacher educators in school improvement, and emphasizes the need for systematic and sustained professional learning opportunities to be provided for them. This policy document echoes long-held professional opinions that teacher educators are the 'linchpins in educational reforms' (Cochran-Smith 2003, p. 3), and that they need more coherent and extensive professional development (Lunenberg, Dengerink, \& Korthagen, 2014).

Also in 2013, the above mentioned International Forum for Teacher Educators Development (InFoTED) was established. The founders explained their initiative as follows:

In our four different European countries - Belgium (Flanders), England, the Netherlands and Norway - we have each developed initiatives to support the professional development of teacher educators nationally, carried out research on the occupational group and tried to speak out to influence our respective policy-makers and governments. All of us have also worked on these issues in transnational contexts. (...) We have long been interested in the potential of teacher educators' learning across and within different European contexts. In many ways our interests start from what Michael Schratz $(2014$, p. 2) calls 'raising awareness for a new expectation of what constitutes a European teacher i.e. a teacher educator working within a European context of professionalism'; our own agenda adapts this call to focus on the idea of what might constitute a European teacher educator and the professional learning she/he might need to operate effectively in both national and transnational contexts (Lunenberg, Murray, Smith, \& Vanderlinde, 2016).

The mission of InFo-TED, which has since extended to include Ireland and Scotland, is 'to bring together, exchange and promote research, policy and practice related to teacher educators'

\footnotetext{
${ }^{4}$ https://velov.files.wordpress.com/2012/02/velov_bro_en_111206.pdf

${ }^{5} \mathrm{http} / / /$ ec.europa.eu/dgs/education_culture/repository/education/events/2012/educator/hungary_en.pdf
} 
professional development'. So far, InFo-TED developed a conceptual model for the professional development of teacher educators, carried out an extensive survey to map the professional needs of teacher educators, developed a virtual learning platform and organized a summer academy to increase opportunities for teacher educators' professional development as well as to encourage them to become leaders in teacher education in their own jurisdictions ${ }^{6}$.

\section{Self-study as practitioner research}

Along with the increasing attention to the professional development of teacher educators, both the broad familiarity with practitioner research in Europe and the academic sceptics are contextual factors to consider when we look into self-study research in Europe. The borderline between practitioner research and a structured reflection on a particular practice proves thin, which - also in Europe - frequently led to critical discussions about the quality of practitioner research (Lunenberg, Ponte, $\&$ Ven, 2007). Without a solid theoretical embedding and a public scrutiny that reviews quality there is only a story, no study (Loughran, 2008). As Loughran and Northfield (1998) stated:

"Reflection is a personal process of thinking, refining, reframing and developing actions. Self-study takes these processes and makes them public, thus leading to another series of processes that need to reside outside the individual ... the generation and communication of new knowledge and understanding" (p. 15).

The specific focus of self-study research requests careful attention for these quality criteria.

Whitehead, who from the beginning has represented an important English contribution to the development of self-study, stated that self-study presented the challenge of a' living contradiction': researching the ' $I$ ' requires stepping back from the ' $I$ ' (1993). Self-study research is distinguished from other types of practitioner research by its focus on the 'I' (Coya \& Taylor, 2009), on the teacher educator him- or herself in relation to his or her practice. Samaras and Freese (2006) describe the paradox aspect of self-study research: individual and collective, personal and interpersonal, and private and public. Public, because, knowledge development is crucial to ensuring that self-study extends beyond the individual and offers more than 'just a story' (Berry \& Kosnik, 2010).Therefore self-study needs to be both self-initiated and interactive (LaBoskey, 2004).

In sum: The increasing attention for the professional development of teacher educators and the existing tradition of practitioner research could be a fertile soil for self-study research. But do European teacher educators accept the challenge of self-study research?

\section{Self-study research in Europe}

From the beginning of the American Education Research Association's (AERA) special interest group Self-Study of Teacher Educators Practices (S-STEP), individual European teacher educators have been involved in S-STEP: Fred Korthagen from the Netherlands was discussant at the 1992 AERA symposium 'Holding up the Mirror: Teacher Educators Reflection their own Teaching' (Loughran, 2004), that lead to the establishment of S-STEP a year later. In the first edition of the International Handbook of Self-Study of Teaching and Teacher Education Practices (Loughran,

\footnotetext{
${ }^{6}$ http://info-ted.eu/
} 
Hamilton, LaBoskey, Russell, 2004), contributions from Belgian, Icelandic, English, and Dutch authors were included.

To map the development of self-study research in Europe since 2004 we searched the Castle Conference Proceedings from 2006-2016. We found multiple contributions from England, Iceland, Ireland and the Netherlands (see below) and some contributions from Czechia (Svojanovsky \& Nehyba, 2016), and Scotland (Griffiths, et al. 2008a/b; Jess, Atencio, \& Carse, 2016). We also searched Studying Teacher Education (Volumes 2013 -2017) and used our networks to locate other self-study initiatives. In Flanders, Vanassche and Kelchtermans facilitated a self-study group from 2009 to 2011, which was extensively studied and resulted in the Ph.D. thesis of Vanassche (2014) and a Flemish Section in Ritter et al. (2018), among other publications. To complete our search an email was sent to all members of S-STEP to invite European colleagues to share their self-study activities with us. This invitation did not lead to additional information.

In the remainder of this section we focus on four self-study communities that have existed for more than one or two years and share their work publicly. We report on developments in 1. England, 2. Iceland, 3. Ireland, and 4. The Netherlands. Then, in the final section we will look across these countries into some common themes and reflect on the future of self-study research in Europe.

\subsection{The development of self-study research in England}

In England, the development of self-study research, which is specified as such, started from small beginnings. It has not become so rapidly or extensively embraced by the teacher education community as in the USA and Australia or even in other European countries such as the Netherlands. It appears to exist in pockets of practice across the country, driven by local interests and needs, which reflects the rapidly changing, fragmented and competitive context of teacher education in England (Hayler, 2010; Jackson and Burch, 2016; McNamara et al., 2017). The term 'self-study' is not familiar to many teacher educators and is not often included in consideration of ways that teacher educators undertake practitioner research (for example: Boyd and White, 2017; Philpott, 2014). The focus tends to be towards reflective practice (Schon, 1987) or inquiring into professional practice through action research (McNiff, 2013). English colleagues may see their 'self-study' research as a case study (Vázquez, 2014); autoethnography (Hayler, 2010); narrative inquiry (Hayler, 2010); reflective narrative (Akinbode, 2013); reflective practice (White, 2011) and action research (Whitehead, 2008). The Collaborative Action Research Network (CARN) founded in 1976 in the UK aims to encourage and support action research projects, including personal projects; making the accounts accessible and contributing to the theory and methodology of action research (https://www.carn.org.uk). There are strong commonalities between self-study, personal action research carried out within a collaborative network, autoethnography and selfnarrative inquiry; each drawing on reflection and inquiry in order to improve one's practice; interaction with critical friends and professional literature; and contributing to the professional knowledge of teacher educators.

Within many Higher Education Institutions, there has been an expectation for teacher educators to carry out research as part of their role (Murray et al., 2011). An issue with the use of self-study could be the extent to which universities accept this methodology as an acceptable research approach to include in their submission for the Research Excellence Framework (REF) through which English universities receive financial reward for contributing to the knowledge base (www.REF.ac.uk). The term self-study could suggest 'navel gazing', a lack of rigour and an inability to contribute to the evidence-base for teaching because of the difficulty of generalizing from 
small-scale research. There may also be an ill-founded assumption that self-study, along with other practitioner research, is simplistic, individualistic and lacks theoretical underpinning.

\section{Influences on the growth of self-study in England}

The biennial 'Castle Conference' of S-STEP, held at Herstmonceux Castle in England has been significant in the development of self-study in England, along with the journal of this association, Studying Teacher Education. In 2006, a group of researchers from two English universities presented an interactive exhibition to explore their workspaces using visual- and image-based methods (Griffiths et al., 2006) at the Castle Conference. Mike Hayler, of the University of Brighton, participated in the Castle Conference in 2008 and at the following conference contributed a paper about self-narrative and the pedagogy of teacher educators (Hayler, 2010). In 2016, he collaborated with Judy Williams (from Australia) to present a paper about their learning as co-editors, as a less considered aspect of the practice of teacher educators (Williams and Hayler, 2016). Kerry Jordan-Daus, from Canterbury Christ Church University, contributed to the conference in 2014 with colleagues about their experiences of a new self-study group that she had instigated as Head of Department (Wilson et al., 2014). In 2016 her paper in the proceedings was about finding her way as a leader (Jordan-Daus, 2016). Also in 2016, Bryan Clift, of the University of Bath, and his mother Renee, wrote a paper about the tension of moving between institutions and their roles as academic and family member (Clift and Clift, 2016). These authors have also published an article in Qualitative Inquiry using shared family histories, memories, and experiences in their self-study of education practice (Clift and Clift, 2017). Daniel Vázquez was one of only two academics from English Universities to publish in Studying Teacher Education between 2013 and 2017 with his reflections on tutoring ancient Greek philosophy to first-year undergraduates at Kings College, London (Vázquez, 2014).

The work of Whitehead in developing self-study masters and doctoral groups has been the largest influence on developing a self-study community in England. He has developed a Living Educational Theory, which is a form of self-study because the ' $I$ ' of the researcher is at the heart of the inquiry (Huxtable and Whitehead, 2017), but also embraces the values of the researcher that 'carry hope for the flourishing of humanity' (Huxtable and Whitehead, 2017). The website at http://www.actionresearch.net is the main forum supporting a Living Educational Theory approach to research, where members explain the enactment of their own self-study methodologies in improving practice and contributing to educational knowledge. Available from this website is the Educational Journal of Living Theories (EJOLTS) which provides evidence on the enactment of self-study methodologies in professional learning; a community space; a postdoctoral research group and a research support group. Jack Whitehead and Marie Huxtable wrote two papers for the 2008 Castle Proceedings, exploring the implications of living educational theories for self-study (Whitehead, 2008; Whitehead \& Huxtable, 2008). Each year they have continued to be part of the S-STEP SIG community, presenting the development and explication of living theory methodology, including the exploration of the use of digital multimedia narratives to enable more valid communications of the meanings of the explanatory principles of S-STEP researchers (Whitehead \& Huxtable, 2010; Whitehead, 2014; Whitehead \& Huxtable, 2014). In 2016 they contributed their own self-study of improving their contribution to the professional development of educational practitioners (Huxtable \& Whitehead, 2016).

\section{Emerging patterns in English self-study}

One of the ways that self-study has been successfully used in England by practitioners is around transition into becoming a teacher educator (Chivers et al., 2010; White, 2011); experiencing 
transition between roles within teacher education (Jordan-Daus, 2016; Williams and Hayler, 2016) and life transitions (Clift and Clift, 2016; Clift and Clift, 2017). This links with an exploration of identity development in teacher education. In the research project described by Chivers et al., (2010) six novice academics in a University education department undertook a year-long exploration of transition into their new roles. Facilitated by more experienced colleagues, they met together regularly to share their challenges and achievements. They focused on their perspectives and emotional responses to working in this new environment and documented this through visual representations at each meeting. These were collated and analysed at the end of the year. The visual approach was particularly powerful in enabling participants to share their emotional journeys and served to demonstrate their growing confidence and the development of their new identities. Visual and multi-media methods have also been effectively used in other selfstudies for example (Griffiths et al., 2006; Whitehead, 2008; Whitehead, 2014; Whitehead and Huxtable, 2014). Collaboration within the group aided critical reflection and a rigorous approach.

Interest in self-study in the School of Education, University of Hertfordshire was initially developed from a reflective practice group of teacher educators led by Helen Burchell. Burchell was interested in narrative and visual approaches to research and how this could be used in inquiry into practice and she connected to Jean Clandinin and other North Americans through the AERA. Here she met American and Australian colleagues who were leading self-study approaches and she introduced their ideas to the School. Jarvis undertook a self-study into her teaching of students in the field of special educational needs and Burchell acted as her critical friend. Engagement with the wider self-study community developed when Burchell and Jarvis presented a paper at the Castle Conference 2006 on the role of dialogue in developing self-study (Jarvis and Burchell, 2006). At this conference they obtained John Loughran's book 'Developing a Pedagogy of Teacher Education' (2006) and a copy of this book was subsequently purchased by the Head of the School for each member of staff in the School. Jarvis led a study of this book, involving lunch time discussions and small enquiries into aspects of our teacher education practice inspired by the text. The text by Russell and Loughran (2007) which documented many examples of self-study was also used by groups of staff as inspiration for thinking about their own practice.

Burchell and Rees attended the Castle Conference in 2008 and in 2010 Chivers presented the results of a self-study group as discussed above (Chivers et al., 2010). After completing the research, participating together in the preparations for the Castle Conference, including writing an abstract, responding to feedback and reviewing the abstracts of others, new colleagues were enabled to participate collaboratively in research processes:

The process and elements of the early academic group described here have eased a transition towards a new identity as an academic. The process has also meant we have become immersed in research and presenting at conferences. This has opened up for me a whole new perspective that I am looking forward to investigating further in formal study programmes and within my practice. I am also keen to continue to develop more new initiatives and feel that the group has given me the professional confidence to do this. (Chivers et al., 2010 p.54)

This enabled them to begin to take on a researcher identity, something that is likely to be new to those coming from schools or pre-school settings. White joined the group later and undertook her own self-study to develop her identity as a teacher educator (White, 2011). 
Alongside these developments Jack Whitehead was invited to speak to colleagues in the School and others undertaking a doctorate in Education. This raised the status of personal inquiry into practice and the significance of self-study in professional development and learning. An experienced teacher educator in the School undertook her doctorate externally using a reflective approach to personal inquiry which involved a study group to support criticality. One of the articles she wrote as a result of this doctoral study was published in Studying Teacher Education, the only other article between 2013 and 2017, from England (Akinbode, 2013). She found the experience of self-study transformational, discovering that 'by opening reflective spaces, one can become aware of how emotions have a powerful impact on the rational aspects of being a teacher' (p.72). She concluded that 'as a result of engaging in this process of self-study, I have become more mindful of what is taking place in my practice as a teacher and more aware of my emotions and my responses to them' (p.72).

Looking back at these developments, a clear thread emerges of engagement in self-study by colleagues in the School of Education, University of Hertfordshire. It was built through people working together in the School and being inspired by people and texts from the wider self-study community, particularly those from North America and Australia. The role of the Castle Conference was also key in making connections and providing an opportunity for engaging with the community. It is interesting that we did not recognize this thread of engagement ourselves until it was pointed out to us by Lunenberg in 2017! Having now told the story of our development in this field we are determined to build on these foundations and to move the narrative forward.

\section{Going forward}

England is ripe for a growth in the use of self-study groups to support the induction and professional development of teacher educators within and across settings. The Castle Conference should try to become more visible to teacher educators within England, as it is a strong opportunity to develop self-study and collaborative international partnerships in this field. Going forward, it may prove useful for people within England who use this method to connect more with each other as well as the international community.

\subsection{Developing Self-study of Teacher Education Practice in Iceland}

Action research as a form of practitioner research has been developing in Iceland from the eighties, beginning with courses for in-service teachers in 1984. This can be seen as the groundwork for introducing self-study of teacher education practice (S-Step) since some of the teachers participating in these action research courses later became teacher educators at the University of Iceland and brought with them the professional activity of reflection on their practice. Teacher education was situated at the upper secondary level until 1974 when it moved to bachelor level and in 2012 to master level. in the same process, the research task of teacher educators grew. That became an additional difficulty in the transition from being a teacher to becoming a teacher educator, which next to teaching people to become teachers, is already a complicated task (Loughran, 2014).

Around the turn of the millennium Dr Hafdís Guðjónsdóttir began her career as a teacher educator. She had been conducting action research for more than a decade but at S-Step sessions at the AERA conference in 1999 she learnt about self-study of teacher education practices as a research methodology. She discovered that self-study offers a frame for teacher educators to 
critically reflect on their practice and a forum to understand what they do, how and why they do it, and how this can help to improve their practice and to make their study public (Samaras, Guðjónsdóttir, McMurrer \& Dalmau, 2012). In addition, the researcher gains an ontological sense of her stance in the professional world and creates a space for dialogue about her knowledge and for understanding of her own practice (Pinnegar \& Hamilton, 2010). This appealed to Hafdís and she adopted the methodology as she became a teacher educator. She collaborated with colleagues around the world, especially with Dr. Mary Dalmau, a teacher educator at Victoria University in Melbourne. As they developed as teacher educators they published their work in chapters and articles, for example: Framing professional discourse with teachers (Dalmau \& Guðjónsdóttir, 2002); Revisioning And Recreating Practice: Collaboration in Self-Study (Bodone, Guđjónsdóttir, \& Dalmau, 2004); Transformative Pathways: Inclusive Pedagogies in Teacher Education (Guðjónsdóttir, Cacciattolo, Dakich, Davies, Kelly, \& Dalmau, 2007); and On fire for teacher education: enacting active scholarship (Dalmau, \& Guđjónsdóttir, 2012).

Iceland University of Education (IUE)

Self-study of teacher education practices is not a common practice at the Iceland University of Education (IUE). In 2004 the first course on action research was offered at the IUE. Since then, the course is offered annually and has good attendance. Gradually, qualitative research gained recognition and respect, and masters studies were conducted using action research methodology. Many of these studies were from teachers looking into their own teaching or work in education. However, these studies were not focused on the self or on how the practitioner was developing or transforming, but more on how the practice was developing and changing. The formal claim for recognition of self-study methodology came with a doctoral study in education by Hafpór Guđjónssons, who in 2002 defended his thesis titled Teacher Learning and Language: A Pragmatic Self-Study. With this research, self-study formally emerged in Iceland. His doctoral thesis was followed by three more doctoral self-studies. Karen Rut Gísladóttir (2011) wrote "I am deaf, not illiterate": a hearing teacher's ideological journey into the literacy practices of children who are deaf (see also Gísladóttir \& \& Guđjónsdóttir, 2014 and Gísladóttir, 2014), Jónína Vala Kristinsdóttir (2016) presented Collaborative inquiry into mathematics teaching: Developing a partnership in researching practice in primary grades and teacher education (see also Kristinsdóttir, 2010), and in 2017 Edda Óskarsdóttir finished Constructing support as inclusive practice: A self-study.

In 2015 Hafdís, Jónína, Karen Rut, Svanborg Rannveig and Edda decided to study how they became self-study researchers. They conducted reflective focus group meetings to discuss their development. Data was collected through recordings, that were transcriped and analyzed. Hafdís used the methodology of self-study of teacher education practice to further develop as a teacher educator and to create courses. She continued to develop and publish her work consistently. When, a few years after she had finished her doctoral thesis, Jónína came back to the University, she and Hafdís collaborated and conducted a self-study when creating and teaching a course for teachers in mathematics and inclusion. Jónína was very knowledgeble about action research and she described her move to self-study as follows :

When I got to know action research I was very pleased with the frames offered and as I began to use the method I found it very helpful to have these guiding lights to support my research. The frames with the action research cycle were not limiting and I wasn't worried that I was doing things in the right or the wrong order. Then when I got to know self-study it felt the most natural thing in the world (Reflective focus group meeting, February 2nd, 2015). 
Hafdís and Jónína published their work in chapters and articles, for example: Teaching all children mathematics: How self-study made a difference (Guðjónsdóttir \& Kristinsdóttir, 2006) and TeamTeaching About Mathematics for All Collaborative Self-Study (Guðjónsdóttir \& Kristinsdottir, 2011). In 2012, Hafdís and Svanborg began teaching together. Svanborg was a new university teacher and got to know self-study as she and Hafdís studied their collaboration and teaching in one of their courses (Guðjónsdóttir \& Jónsdóttir, 2012; Guđjónsdóttir \& Jónsdóttir, 2016; Jónsdóttir \& Gísladóttir (2016). She found self-study a rational way to research her practice and to reflect on her role in implementing the innovative elements they were trying out. However, as she started to mention this method to some colleagues they frowned upon it and made some demeaning remarks. Svanborg reflected on her experience:

If I look back on how I experienced beginning with self-study with Hafdís on our course Teaching diverse groups of students, it felt so sensible. But we lacked the words in Icelandic that properly covered the English concept self-study. We wrote about our findings in Icelandic using the words"kennarar rannsaka eigið starf" ("teachers research their own work") for self-study. It was somehow as if self-study was banned as a word in our language - and we were looking for the proper expression to use in Icelandic (Reflective focusgroup meeting, February 2nd, 2015).

Svanborg did not let what our colleagues said about self-study affect her too much and carried on with self-study together with another colleague, Karen Rut, and with Hafdís, publishing both in Icelandic and English (Guđjónsdóttir, Gísladóttir, \& Jónsdóttir, 2014). The process empowered her to become the university teacher she wanted to be. In her words:

I also discovered that the research process helped me and my colleagues to respond to students needs and make our courses more influential in a positive way. In the collaborative self-study projects with Karen and Hafdís I have learned to analyse my visions, uncover my values and beliefs and I have developed my professional identity (Reflective focusgroup meeting, February 2nd, 2015).

Their collaboration turned into a publication on teacher education practice in Icelandic and was used as an opportunity to broader introduce S-Step in Iceland. Initially this became an issue for the editors of the journal, because they did not understand self-study methodology (one example about yourself: how can you generalize the findings?), but after some explanation the study was published.

Looking over the history of the development of self-study in Iceland we can see that action research and self-study have gained ground in Icelandic research hand in hand with the development and acknowledgement of qualitative research. With qualitative research gaining recognition, the visibility of the researcher is more often considered a strength rather than a weakness. This has lead to a different view in which the self has started to emerge as an important part of the research process and findings. However, self-study of teacher education is not a common practice of many Icelandic teacher educators, but it is a strength for teacher educators who practice it.

\section{Moving on}

Our experience with introducing self-study in Iceland has met with a lack of understanding and knowledge about the methodology in our professional community, and with prejudice that has appeared as demeaning remarks about the usefulness and respectability of the method, or as 
disinterest. Developing a community of teacher educators engaging in self-study, however, is becoming a reality that we hope will spur others to engage in self-study. A key to such development is presentation and publication in Icelandic and finding the Icelandic words that convey the core of the methodology.

From 2013, Hafdís, Karen Rut and Svanborg have teamed up and collaborated as teacher educators and self-study researchers. They have developed collaborative supervision for students working on their master projects and published their work as articles and chapters: Using SelfStudy to Develop a Third Space for Collaborative Supervision of Master's Projects in Teacher Education (Jónsdóttir, Guđjónsdóttir, \& Gísladóttir, 2015); and Collaborative Supervision: Using Core Reflection to Understand Our Supervision of Master's Projects (Guđjónsdóttir, Jónsdóttir, \& Gísladóttir, 2017). Moreover, they transformed a course on inclusive education building on the data from their self-study. This study was published in Creating Meaningful Learning Opportunities Online (Guđjónsdóttir, Jonsdottir, \& Gísladóttir, 2015).

This small group of teacher educators that has developed as a self-study research team has learned that collaborative self-study of shared teaching and learning experiences can help draw out the complex thinking, decision making, and pedagogical rationale that supports the professional work of teacher educators. Analyzing our vision, values and beliefs can help us gain an understanding of our professional identity and become active change agents (Dalmau \& Guðjónsdóttir, 2002; Loughran, 2014). In this writing we have tried to shed a light on how a group of scholars in our country created and developed a self-study discourse in their professional community.

\subsection{The story of a sport pedagogy self-study group in an Irish university}

\section{Introduction}

Self-study in Ireland appears not to be as well-established as in other countries. We found two publications of Nona Lyons and Carmel Halton (University of Cork) who, together with Heleen Freidus (USA), studied their critical roles as facilitators of reflection in transformative learning in three different setting (Lyons, Halton, \& Freidus, 2012, 2013). A third article was by Annelie Eberhardt (with Manuela Heinz, 2017) who, coming from Germany to Ireland, reflected on the messiness of action research while studying how she can support teachers in becoming critical inquirers of their own classrooms. Worth mentioning is the website of the Network for Educational Action Research in Ireland which sets out 'to explore the appropriateness of self-study approaches to action research for practitioners' (http://www.eari.ie/neari-network-for-educational-actionresearch-in-ireland/).

We focus in this section on conveying the story of how self-study has brought together a group of sport pedagogues in the University of Limerick to consider opportunities for collaborative teaching and research. We outline what sport pedagogy is and who the members of the group are before focusing on our work to date in self-study and current self-study projects. All members of the sport pedagogy group identify as physical education teacher educators, appreciating that this is a sub-discipline of sport pedagogy. With this specific shared identity, self-study research provides a method for systematic inquiry into teaching and teacher education, encouraging a network of practitioners / researchers who bring an inquiry-oriented stance toward researching their own practice. 
Sport pedagogy is the joining of education and sport. In its broadest context, sport pedagogy includes physical activity, physical education, wellness and sport for all age groups. Sport pedagogy is evidenced-based and practice-focused, built on a foundation of effective teaching and coaching, and aimed at promoting participants' learning (Armour, 2011).

The complement of sport pedagogues in the University of Limerick reside in the Department of Physical Education and Sport Sciences and include two professors, one senior lecturer (emeritus), four lecturers, two Applied Studies Coordinators and four doctoral students. All are involved in teaching in the two physical education teacher education (PETE) programmes. Half of the group have doctoral degrees while the others are studying for doctoral degrees as full time staff members or fulltime doctoral students who have come predominantly from teaching school level physical education. This allows a cross-fertilization of academic staff ideas on teaching and PETE with the modern realities of schooling that the Applied Study Coordinators bring with them. Encouraging such networks within PETE programmes not only strengthens the sense of a shared community of practitioners / researchers but also encompasses a level of programme accountability in providing evidence of the extent to which a PETE programme effectively provides teachers and pre-service teachers (PSTs) with intended experiences. A number of the group are internationally respected as sport pedagogues and have contributed significantly to the research literature in the sport pedagogy domain through the publication of books, book chapters and peer-reviewed papers.

Focus of published self-study work and ongoing self-study projects within the group Several members of the group have amassed self-study research outputs that focus on their experiences of being a teacher educator (MacPhail, 2017, 2014, 2011; Tannehill, 2014), being members of a teacher education learning community (MacPhail et al., 2014; Parker et al., 2016; Tannehill et al., 2016) and considering the continued and future use of self-study as physical education teacher educators (Ní Chróinín et al., 2016; O'Sullivan, 2014). This ongoing interest in self-study frames a number of projects that the group is currently undertaking and we would like to expand on three particular projects here. The first two reside within the group of sport pedagogues at the University of Limerick while the third provides an example of working across institutions and countries.

Project 1: Encouraging colleagues to explore their identity and practices through self-study Five members of the sport pedagogy group had a shared symposium accepted for a US conference in March 2015. The group included three established researchers in self-study and two colleagues who were new to self-study. Indeed, this was one colleague's first research writing endeavour. Between the established researchers presenting an introduction to self-study, exploring our move as a sport pedagogy faculty from focusing on the 'me' to ' $u$ ' and concluding the session, the two colleagues who were new to self-study presented on their self-study of (i) being commonly identified as the 'adapted physical activity person' and (ii) their feeling of 'going back to school' in being prompted to consider their positioning as a teacher educator, a dance educator and a dancer. All five presenters worked successfully on securing a peer-reviewed publication from the work (Tannehill et al., 2016).

Project 2: A collegial involvement in self-study

The aim of this research is to undertake collective teacher education self-studies on the enactment of curriculum and instruction models within a PETE programme to enhance our understanding of how a close collegial self-study teacher educator community of practice can support each other. 
The research entails physical education teacher educators aligning themselves to a specific curriculum and instructional model they will deliver throughout a module on the undergraduate programme. The teacher educators will work in groups of three with one person responsible for the delivery of the model, a second person acting as a critical friend on a weekly basis to that person, and a third person prompting the research component of the initiative. Such promoting can include encouraging weekly documentation of delivery and associated experiences and discussions with the critical friend documenting the teacher educators' and PSTs' perspectives of the specific curriculum and instructional model. All three members of the group will contribute to a collective self-study of their involvement in the initiative.

\section{Project 3: Self-study and meta-critical friendship}

International engagement across teacher education programmes has been an element of our selfstudy work (Ní Chróinín, \& Fletcher \& O’Sullivan, 2015; 2017). Three physical education teacher educators (two from Ireland and one from Canada) have collaborated to develop and implement new pedagogical approaches in two PETE programmes. Additionally, we have sought to describe and interpret how two distinct layers of critical friendship were used to support the pedagogical innovation in PST education (Fletcher, Ní Chróinín, \& O’Sullivan, 2016; Ní Chróinín, O’Sullivan, \& Fletcher, 2016). Across a two-year period we experimented with a pedagogical practice we named LAMPE (Learning about Meaningful Physical Education) integrating it into the teacher education programmes of both prospective primary and secondary teachers of Physical Education. Critical friendship was applied in two ways: (1) the first two authors served as critical friends to each other as they taught their respective teacher education courses using LAMPE, and (2) the third author acted as a meta-critical friend, providing support for and critique of the first two authors' development and enactment of the innovation. Over two years, the two layers of critical friendship held significant benefits in advancing and supporting the development of the innovation while also contributing to the professional learning of all participants. The role of meta-critical friend (in this case a senior academic) was in collaborating with two early to mid-career academics in supporting their pedagogical innovations. It involved three distinctive roles as a meta-critical friend in the three-way conversations that are a feature of the self-study projects. One was as a "connector of ideas", seeking to support two colleagues to gain a broader perspective on the research. A second role was an "interrogator of ideas" which allowed the critical friend to probe and help their colleagues to better articulate principles of practice of this pedagogical approach and positioning it within the wider literature. A third position of the meta-critical friend was as a "mediator" in challenging colleagues to examine the nature of their research relationship pushing the boundaries of how they acted as critical friends. This role drew on Fullan's (1993) concept of teacher change in moving beyond politeness in earlier interactions to more critical interrogations of each other's practices and thinking.

\section{Closing remarks}

The group are interested in extending their investment in self-study through potential future deigns including (i) across programme and department collaborations around a theme and, (ii) across PETE programmes and physical education teacher educators nationally and internationally.

\subsection{Self-study research in the Netherlands}

Dutch teacher educators have a rich background in teaching, but their research background is often limited, also because traditionally most teacher educators have no research time. In the last decade, however, a shift can be noticed. Student teachers are more often requested to carry 
out a research project in their final year of teacher education, thus teacher educators are expected to support student teachers to do so. This is one of the reasons that the attention for teacher educators' research capabilities has increased. In this context, in 2007, Lunenberg, Korthagen, and Zwart (2010a) started the first Dutch self-study project called: "Self-study: Teacher educators study their own practice" 7 . The naming of the project showed that, like in Iceland, we were struggling with a translation of 'self-study research' that was meaningful in the Dutch context without losing the self.

The project aimed to contribute to the introduction of self-study research in the Netherlands as well as to support the participating teacher educators to further develop their scholarship. During a year a small group of teacher educators from different teacher education institutions, together with the facilitators, met monthly, and in between the meetings the participants got individual support. Since then, this initiative was followed up by two more selfstudy trajectories, in 2008 and in 2015 (Berry, Van den Bos, Geursen, \& Lunenberg 2018), a five year long self-study community from 2009 to 2013 (Lunenberg, et al., 2012) and a self-study writing group from 2016 to 2018 (Lunenberg et al., 2018). All of these self-study activities were extensively studied not only for its effects on the participants but also with the wish to learn more about facilitating self-study research.

Inspired by these loosely connected initiatives, other self-studies initiatives also popped up in the Netherlands. Bronkhorst and Van Rijswijk (Bronkhorst et al., 2013) studied the (dis)continuities they experienced in the transition from being a researcher to becoming a teacher educator and vice versa. Koster and Van den Berg (2014) report about a self-study of six teachers who explored dilemmas that challenged their professional values. De Heer, Van Rijswijk and Tuithof (2018) collaboratively carried out an ongoing self-study on their development as researchers in a shifting landscape: the increasing emphasis on research in their institution, the policy choices that followed, and the consequences of these choices for themselves and their collegial collaboration (see also De Heer, Tuithof, Rijswijk, \& Bronkhorst,2010). Kools $(2017,2018)$ also wrote about the processes in a self-study group she hosted and about the topics the participating teacher educators chose to study.

\section{Learning self-study research}

Researching the self-study activities mentioned above showed that these strongly contributed to the professional learning of the participants (Berry et al., 2018; Geursen et al., 2010, 2016; Lunenberg, Korthagen, Zwart, 2010a, 2010b; Zwart et al., 2008). They helped them to improve their practices, offered them a new perspective on research, and enabled them to better understand the pitfalls student teachers meet in their research projects (Radstake, 2018). Focusing on a specific research theme also helped to get a grip on literature (Lunenberg, Korthagen, Zwart, 2010a, 2010b). Reading academic publications in English does not only require a literal understanding, but also understanding of meaning. Reading literature that was related to a selfchosen research question helped. Interesting, the issue of understanding the meaning of the English language also led to a long term co-operation between a Dutch teacher educator teaching English in the Netherlands (Janneke Geursen), who met at the Castle Conference a Canadian colleague who taught English to French speaking Canadians (Lynn Thomas). This resulted in several collaborative self-studies (for example Thomas \& Geursen, 2013, 2016).

\footnotetext{
${ }^{7}$ Dutch examples of self-studies of Ph.D. students researching their connection with practice are scarce (Lunenberg, et al, 2006; Bronkhorst et al, 2013).
} 
Another important aspect that stimulated learning was working in a group (Lunenberg, Korthagen, Zwart, 2010a; Lunenberg et al., 2018). The safety of the group supported moving through chaos and finding one's path, and it offered emotional support:

"Our community proved to be a safe meeting place, a place where we could inform each other about the discoveries we had made when studying our practices, discussing not only the how, but also the why of our findings and thus contributing to improving not only our personal practices, but also each other's. By analyzing deeper meanings underlying the outcomes, we have "moved beyond the story" (Lunenberg et al., 2012, p. 189).

\section{Identity development}

The results of studies on the 2007 and 2008 self-study trajectories (Lunenberg, Korthagen, Zwart, 2010a, 2010b) revealed that the learning through self-study went deeper than cognitive and practical learning; it also led to identity development (Geursen et al., 2010, Lunenberg, Korthagen, \& Zwart, 2011). In self-study literature, it is often emphasized that self-study research is a productive way to combine teacher educators' dual roles of teacher of teachers and researcher, because self-study research starts with a challenge or problem related to being a teacher of teachers (Loughran, 2014). In the Netherlands, however, most teacher educators only have a role as a teacher of teachers. Hence, for Dutch teacher educators, self-study research is not a way to combine the roles of teacher of teacher and researcher, but a way to extend their teacher educator role as a teacher of teachers and to explore the new role of researcher (Lunenberg et al., 2018). This did not mean that there were only positive feelings with regard to the (new) role of researcher (Lunenberg, et al., 2012). Research became more familiar, but the consciousness of the complexity of research also grew. This led to what Tack and Vanderlinde (2014) call different researcherly dispositions. Some teacher educators defined themselves as teacher of teachers who now knew more about research, others became teacher educators/researchers. In addition to publications mentioned in this chapter, several articles were published in the Dutch Journal of Teacher Educators, and almost every year self-studies were presented at the annual Dutch Conference for Teacher Educators. Going public' had a remarkable effect on self-confidence. Since 2008 participants in Dutch self-study activities also presented their work at the Castle Conference, which was experienced as a highlight:

The huge diversity of self-study approaches, of collecting data, and of presenting surprised me and offered me a lot of new information and ideas. Also the informal meetings were valuable. (...) Mirroring my own practice to the practices of others made me also more conscious of my qualities and my added value as school-based teacher educator (Hagebeuk, 2018).

\section{Facilitating self-study research}

The unfamiliarity of Dutch teacher educators with (self-study) research was the reason to organize the Dutch self-study projects mentioned above and to provide structural support for the participants, offered by experienced self-study researchers. At the beginning a main source of inspiration for the facilitators was the work of Hoban (2007). Since 2007, an increasing number of studies on facilitating self-study research have been published (Davey et al., 2010, 2011; PithouseMorgan et al., 2015; Samaras, et al., 2008; Vanassche \& Kelchtermans, 2015) that further inspired the development of supporting self-study research in the Netherlands. A comparative study (Lunenberg \& Samaras, 2011; Samaras \& Lunenberg, 2010) helped the development of a set of guidelines that could support self-study research. 
Loughran's introduction of the journey metaphor was helpful in naming the Dutch approach Loughran, 2014). It combines space for both individual and collective experiences and the idea of following personal interests in a loosely pre-structured environment. It also helped the facilitators to look into their own role from different perspectives: "What would be my role as a facilitator during the journey: group member, journey leader, luggage porter?" (Berry, Van den Bos, Geursen, \& Lunenberg, 2018).

Self-study research of the facilitators showed the importance of thoughtful pedagogical choices in the meetings. Because most Dutch teacher educators have teaching only positions, they had no outspoken opinion about the facilitators' research expertise, but they were quite alert to the pedagogical approaches used. Hence, the thoughtful pedagogical approaches helped to build trust and feelings of safety (Lunenberg et al., 2018).

One other specific issue of facilitating Dutch self-study activities was meeting participants' methodological doubts about reliability and generalization and discussing the challenging idea of going public with a personal study (Lunenberg, Korthagen, Zwart, 2010a, 2010b). These issues contributed to a risk of losing the ' $I$ ' when participants had to translate a practical challenge into a research question. In a reflective article one of the participants remarked:

"I think culture plays a very important role here, and not just research culture. There is a tendency in the Netherlands to be rather critical of others, but also of ourselves. Being open, sharing insecurities, and even showing achievements is not really encouraged. And although the value of critical reflection backed by theory is recognised by many teacher educators, you still feel the fear of being considered "soft" (Berry, Geursen, \& Lunenberg, 2015, p 47).

Hence, Dutch facilitators had to take into account the cultural context in which a self-study was carried out. The study of Vanassche in Flanders, a country with a comparable culture, also emphasized the importance of this aspect (Vanassche, 2014, Vanassche \& Kelchtermans, 2015).

\section{Self-study research in Europe: present and future}

The aim of this chapter was to offer insight into the positioning and development of self-study research in Europe; to demonstrate the contribution of self-study research to the professional development of European teacher educators and to the international knowledge base of teacher educators; and to reflect on the further development of self-study research in Europe.

This aim is ambitious, taken into account that Europe is a patchwork of countries, cultures and languages. Looking more specifically at teacher educators in Europe, we see a broad variation in background, tasks and opportunities for professional development. The attention to teacher educators' professional development in Europe started in the beginning of this century and while this attention is spreading, the situation per country still varies from structural approaches to no approaches at all. On a policy level, the European Commission publication Supporting Teacher Educators for Better Learning in 2013 was a milestone. However, the consolidation of this policy document into national policy and practice is a challenge.

The development of self-study research in Europe is intertwined with the professional development of teacher educators. Self-study could also build on existing European traditions in practitioner research, such as action research. 
In this chapter we have explored in-depth the developments in four countries where self-study research has been carried out since the beginning of the century (England, Iceland, Ireland, the Netherlands). As described above, for example, in England and Iceland the familiarity with action research often was a base for teacher educators to further explore what self-study methodology could offer. This building on action research and other forms of practitioner research can also be seen in other European countries, among them Norway (Ulvik, 2014, Smith, 2017). Another stimulation to explore the possibilities that self-study methodology has to offer was the increasing importance of research in countries such as Iceland and the Netherlands where traditionally former teachers were appointed as teacher educators. Consequently, most teacher educators in these two countries did not have a research background and therefore explored ways to become familiar with research. In the Netherlands this led to the initiation of facilitated self-study trajectories. The Irish context reported earlier provides an example of a successful framework where those less familiar with research were welcomed and incorporated into a subject-specific self-study research group.

In all four countries self-study has proved to be a useful and stimulating way to aid the transition from being a teacher - or researcher - to becoming a teacher educator. Self-study methodology not only supported the understanding and development of the teacher education practice, but also led to transformative learning, i.e. to identity development. It helps teacher educators to become conscious about the roles teacher educators fulfil (such as teacher of teachers and researcher, but also curriculum developer, coach, assessor, broker) and how best to position themselves in relation to these roles.

Working together is an important condition for conducting self-study research. As pointed out in the Introduction to this chapter, researching the ' $I$ ' requests stepping back from the ' $I$ ', which cannot be done without critical friends. In the Icelandic situation this entailed working together in a small group. In the Netherlands several self-study trajectories and communities have been organized in the last decade. In England, Iceland, and Ireland self-study research has been developed by collegial groups within a university.

A self-study group offers safe, practical and emotional support, and connects - as can be read in the Irish contribution - the 'me' and 'us', offering meta-critical friendship. In addition, the Irish collaborative self-studies of researchers and practitioners have strengthened the PETE programme at the University of Limerick.

The Dutch contribution emphasizes how the safety of a group helped to overcome doubts, strengthened by a critical culture, about the reliability of self-study research. Dutch and Flemish studies (for ex., Vanassche, 2014, Vanassche \& Kelchtermans, 2015) show that facilitators of selfstudy groups need to take national characteristics, such as a critical culture, into account. Most outspoken in this context is the language issue. In Iceland, as well as in the Netherlands, finding the right words to talk and write about self-study methodology is a challenge, and teacher educators who want to frame their self-studies sometimes struggle to connect their Icelandic and Dutch practices with Anglo-Saxon publications.

In all four countries co-operation across the ocean also plays an important role in the support for and further development of self-study research. Considering the relatively small European selfstudy communities, working together with colleagues from North America and Australia is important. The English section clearly shows how connecting with colleagues abroad, participating in S-STEP activities at conferences, and reading and discussing international literature contributed to the development of self-study research in the School of Education of the University of 
Hertfordshire. In this context the role of the biannual S-STEP Castle Conference in England should not be underestimated. For European teacher educators, this conference has proved to be an important portal to self-study research and to co-operation with colleagues from other countries. It is also important to note that for some attendees, this it is their first experience of 'going public' and of presenting in English.

\section{On the road to the future}

Writing this chapter has helped us to map and get an overview of self-study research in our own four countries and in Europe. So far, the development of self-study research in Europe has been the work of individuals and small groups and the institutional embedding is still limited in the four countries discussed in this chapter, countries that are in the forefront.

On the positive side, this chapter shows what these relatively small initiatives have already contributed to the professional development of teacher educators and also highlights the European contribution to the growing knowledge about self-study methodology.

We see several future chances for self-study research in Europe. As stated in the Icelandic contribution, this chapter shows that only a few active change agents are needed to trigger the development of self-study research in a country.

Moreover, the attention for research in teacher education and for researcherly dispositions of teacher educators in Europe is growing and self-study research can contribute to this growth and help to broaden the professional identity of teacher educators. Also, the increasing consciousness of the influence of different national contexts and different languages can help to develop more tailored initiatives to stimulate self-study research in various European countries.

The section above on self-study research in England, Iceland, Ireland, and the Netherlands also offers practical suggestions for involving more teacher educators in self-study research. A few examples: In Ireland a self-study mentoring scheme has been developed, that is focused on mentoring self-study researchers as well as the critical friends. In the Netherlands pedagogical approaches of supporting self-study groups have been made explicit. In the English contribution participating in the procedures of the Castle Conference is given as a successful example of learning to write and publish, and in Ireland writing short articles for professional journals proved to be productive. Both approaches can also be seen in the Netherlands.

Working together on this chapter has offered us a solid base to further promote self-study research in Europe. We feel it could be interesting to explore the possibility to organize small invited seminars to identify cross-Europe possibilities for self-study research. We also will continue publishing about self-study research from a European point of view, to gain deeper insights into the specific cultural and contextual influences in play within specific, and across, European countries. Working together on self-study research and writing can strengthen our existing connections and build our emerging practice. We look forward to building on these foundations.

\section{References}

Akinbode, A. (2013). Teaching as lived experience: The value of exploring the hidden and emotional side of teaching through reflective narratives. Studying Teacher Education 9, 6273.

Armour, K. (2011). Sport pedagogy. Essex: Prentice Hall.

Berry, A., \& Kosnik, C. (2010). Special issue: A story is not just a story: Many ways to go beyond the story in self-study research. Studying Teacher Education, 6(3), 217-220. 
Berry, B., Geursen, J., \& Lunenberg, M. (2015). A dialogue on supporting self-study research in the context of Dutch teacher education. In Samaras, A., \& Pithouse-Morgan, K. (Eds.), Polyvocal professional learning through self-study research (pp. 39-56). Rotterdam, Boston, Tapei: Sense Publishers.

Berry, M., Van den Bos, P., Geursen, L., \& Lunenberg, M. (2018). Saying 'yes' to the adventure: Navigating a collective journey of self-study research. In J. Ritter, M. Lunenberg, K. PithouseMorgan, A, Samaras, \& E, Vanassche (Eds), Teaching, learning, and enacting of self-study methodology: Unraveling a Complex Interplay (pp. 111-130). Dordrecht, The Netherlands: Springer.

Bodone, F., Guđjónsdóttir, H. \& Dalmau, M. C. (2004). Revisioning and recreating practice: Collaboration in self-study. In John Loughran, Mary Lynn Hamilton, Vicki Kubler LaBoskey, \& Tom Russel (Eds.), International handbook of self-study of teaching and teacher education practices (pp. 743-784). Dordrecht: Kluwer Academic Publishers.

Boei, F., Dengerink, J., Geursen, J., Kools, Q., Koster, B., Lunenberg, M., \& Willemse, M. (2015). Supporting the professional development of teacher educators in a productive way. Journal of Education for Teaching, 41(4), 351-368. DOI:10.1080/02607476.2015.1080403

Boyd, P., Harris, K. \& Murray, J. (2011) Becoming a teacher educator: Guidelines for induction (2nd Ed.). ESCalate, Higher Education Academy: Bristol. Available at www.escalate.ac.uk/8508

Boyd, P. \& White, E. (2017). Teacher educator professional inquiry in an age of accountability. In: Boyd, P. \& Szplit, A. (Eds.,) Teacher and teacher educator inquiry: International perspectives (pp. 123-142). Kraków: Attyka.

Bronkhorst, L. H., van Rijswijk, M. M., Meijer, P. C., Koster, B., \& Vermunt, J. D. (2013). University teachers' collateral transitions: continuity and discontinuity between research and teaching. Infancía y Aprendizaje, 36(3), 293-308.

Chivers, L., Collins, C., Lee, L., Solly, D., Dickerson, C., Jarvis, J. \& Levy, R. (2010). Enhancing the induction process of new teacher educators through a self-study group. In: Erickson, L. B., Young, J. R. \& Pinnegar, S., (Eds). Negotiating the diverse landscape of teacher education. Herstmonceux Castle, Sussex, England (pp.53-56). Provo, Utah: Brigham Young University.

Clift, R. T. \& Clift, B. C. (2016). Family scholar lenses on professional opportunities: Gendered transitions, gendered narratives. In Garbett, D. \& Ovens, A., Eds.), Self-Study of teacher educationpPractices: Enacting self-study as methodology for professional inquiry (pp. 305310). Herstmonceux Castle, East Sussex, England.

Clift, B. C. \& Clift, R. T. (2017). Toward a "pedagogy of reinvention": Memory work, collective biography, self-study, and family. Qualitative Inquiry, 23, 605-617.

Cochran-Smith, M. (2003). Learning and unlearning: The education of teacher educators. Teaching and teacher education, 19(1), 5-28.

Coya,L. \& Taylor, M. (2009). Co/autoethnography: exploring our teaching selves collaboratively. In D.L. Tidwell, M. L.Heston, \& L.M. Fitzerald, (Eds.), Research methods for the self-study practice (pp. 3-16). Dordrecht: Springer.

Czerniawski, G., Guberman, A., \& MacPhail, A. (2017). The professional developmental needs of higher education-based teacher educators: An international comparative needs analysis. European Journal of Teacher Education, 40(1), 127-140.

Dalmau, M.C. \& Guđjónsdóttir, H. (2002). Framing professional discourse with teachers: Professional working theory. In J. Loughran \& T. Russell (Eds.), Improving teacher education practices through self-study (pp. 102-129). London, New York: Routledge/Falmer. 
Dalmau, M.C. \& Guđjónsdóttir, H. (2012). On fire for teacher education: enacting active scholarship. In J. R. Young, L. B. Erickson \& S. Pinnegar (Eds.), The ninth international conference on self-study of teacher education practices. Extending inquiry communities: illluminating teacher education through self-study (pp. 86-89). Herstmonceux Castle, East Sussex, England: Self-Study of Teacher Education Practices.

Davey, R., Gilmore, F., Haines, G., McGrath, A., Morrow, D., Robinson, R., \& Ham, V. (2010). Professional learning through collective self-study: Sharing tales from the field. In L. B. Erickson, J. R. Young, \& S. Pinnegar (Eds.), Navigating the public and private: Negotiating the diverse landscape of teacher education (pp. 69-72). Provo, UT: Brigham Young University.

Davey, R., Ham, V., Haines, G., McGrath, A., Morrow, D., \& Robinson, R. (2011). Privatization, illumination, and validation in identity-making within a teacher educator research collective. Studying Teacher Education, 7(2), 187-199.

De Heer, A. ,Tuithof, H., Rijswijk, M. van, \& Bronkhorst. L. (2010). Invoking self-study in a school adoption project to foster a community of learners. In L.B. Erickson, J.R. Young, \& S. Pinnegar (Eds.), Navigating the public and private: Negotiating the divers landscape of teacher education. Proceedings of the eighth international conference on the self-study of teacher education practices, East Sussex, England (pp. 73-76). Provo, Utah: Brigham Young University.

De Heer, A., Van Rijswijk, M., Tuithof, H. (2018). The Researcher inside me. A quest for meaningful research in a shifting academic landscape. In J. Ritter, M. Lunenberg, K. Pithouse-Morgan, A, Samaras, \& E, Vanassche (Eds.), Teaching, learning, and enacting of self-study methodology: Unraveling a complex interplay (pp.149-162). Dordrecht, The Netherlands: Springer.

Eberhardt, A., \& Heinz, M. (2017). Walk little, look lots: Tuning into teachers' action research rhythm. Studying Teacher Education, 13(1), 36-51.

European Commission (2013). Supporting teacher educators for better learning outcomes. EC.

Fletcher, T., Ní Chróinín, D., \& O’Sullivan, M. (2016). A Layered approach to critical friendship as a means to support pedagogical innovation in pre-service teacher education. Studying Teacher Education, 12 (3), 302-319, DOI:10.1080/17425964.2016.1228049

Fullan, M. (1993). Change forces: Probling the depths of education reform. New York: Routledge. Geursen, J., Heer, A. de, Korthagen, F., Lunenberg, M.L. \& Zwart, R.C. (2010). The importance of being aware: developing professional identities in educators and researchers. Studying Teacher Education, 6(3), 291-302.

Geursen, J., Berry, A., Hagebeuk, E., Peters, C., \& Lunenberg, M. (2016). Learning together as teachers and researchers: Growing shared expertise in a self-study community of inquiry. In Garbett, D., \& Ovens, A. (Eds.). Enacting self-study as methodology (pp. 59-62). Auckland, New Zealand: University of Auckland.

Gísladóttir, K. R. (2011). "I am deaf, not illiterate": a hearing teacher's ideological journey into the literacy practices of children who are deaf. Dissertation. Reykjavík: University of Iceland.

Gísladóttir, K. (2014). "Tjaa, I Do Have Ears, But I Do Not Hear": New literacy studies and the awakening of a hearing teacher. Studying Teacher Education 10(2) DOI:10.1080/17425964.2014.910760

Gísladóttir, K. \& Guđjónsdóttir, H. (2014). Confronting the hearing teacher in deaf education: A collaborative self-study University of Iceland. In Garbett, D. \& Ovens, A. (Eds.), Changing practices for changing times: Past, present and future possibilities for self-study research (pp. 97-102). Herstmonceux Castle, East Sussex, England.

Griffiths, M., Kibble, B., Houston, N., Cuttin, J., Easton, R, Gemmel, T., Malcolm, H., Robinson, J., \& Ross, H. (2008a). A research culture of our own. In M. Heston, D. Tidwell, K. East \& L. 
Fitzgerald (Eds.), Pathways to change in teacher education: Dialoge, diversity and self-study (pp. 153-157). Ceder Falls: University of Northern lowa.

Griffiths, M., Douglas, R., Gizzi. A., Malcolm, H., \&Williamson, Z., (2008b). Selves and spaces and Doing Research. In M. Heston, D. Tidwell, K. East \& L. Fitzgerald (Eds.), Pathways to change in teacher education: Dialogue, diversity and self-study (pp. 158-162). Ceder Falls: University of Northern lowa.

Griffiths, M., Poursanidou, D., Simms, M. \& Windle, J. (2006). Defining workspaces, defining ourselves. In: Fitzgerald, L. M., Heston, M. L. \& Tidwell, D. L. (Eds.), The Sixth international conference on self-study of teacher education practices. Collaboration and community: Pushing boundaries through self-study (pp. 288-289). Cedar Falls, lowa: University of Northern lowa.

Guðjónsdóttir, H., \& Jónsdóttir, S. R. (2012). Preparing teachers for teaching a diverse group of learners in a changing world. In J. R. Young, L. B. Erickson \& S. Pinnegar (Eds.), The Ninth international conference on self-study of teacher education practices. Extending inquiry communities: Illuminating teacher education through self-study (pp. 151-154).

Herstmonceux Castle, East Sussex, England: Self-Study of Teacher Education Practices.

Guðjónsdóttir, H. \& Jónsdóttir, S. (2016). Emancipatory pedagogy for inclusive practices, enacting self-study as methodology. In Garbett, D., \& Ovens, A. (Eds.). Enacting self-study as methodology (pp. 299-304). Auckland, New Zealand: University of Auckland.

Guđjónsdóttir, H., Jónsdóttir, S. R. \& Gísladóttir, K. R. (2017). Collaborative supervision: Using core reflection to understand our supervision of master's projects. In Brandenburg R., Glasswell K., Jones M., Ryan J. (Eds.), Reflective theory and practice in teacher education. Self-study of teaching and teacher education practices (pp. 237-255). Singapore: Springer.

Guđjónsdóttir, H., Gísladóttir, K., \& Jónsdóttir, S.(2014). Collaborative supervision of master's projects: A self-study by three university-based teacher educators. In Garbett, D. \& Ovens, A. (Eds.), Changing practices for changing times: Past, present and future possibilities for selfstudy research (pp. 112-114). Herstmonceux Castle, East Sussex, England.

Guđjónsdóttir, H., Jónsdóttir, S. R. \& Gísladóttir, K. R. (2015). Creating meaningful learning opportunities online. Bank Street Occasional Paper Series 34. Retrieved:

http://www.bankstreet.edu/occasional-paper-series/

Guđjónsdóttir, H. \& Kristinsdóttir, J. V. (2011). Team-teaching about Mathematics for all. Collaborative self-study. In Suck, S. \& Pereira, P. (Eds.), What counts in teaching mathematics: Adding value to self and content(pp. 29-44). Dordrecht: Springer.

Guðjónsdóttir, H. \& Kristinsdóttir, J. V. (2006). Teaching all children mathematics: How self-study made a difference. In Tidwell, D. \& Fitzgerald, L. (Eds.), Self-study and diversity (pp. 195212). Rotterdam: Sense Publishers.

Guðjónsdóttir, H., Cacciattolo, M., Dakich, E., Davies, A., Kelly, C. \& Dalmau, M. C. (2007). Transformative pathways: Inclusive pedagogies in teacher education. Journal of Research on Technology in Education (ISTE). 40(2), 165-182.

Guđjónsson, H. (2002). Teacher learning and language: A pragmatic self-study. Dissertation. Vancouver : University of British Columbia Library.

Hagebeuk, E. (2018). Experiences of a school-based teacher educator: A vignette. In J. Ritter, M. Lunenberg, K. Pithouse-Morgan, A, Samaras, \& E, Vanassche (Eds), Teaching, learning, and enacting of self-study methodology: Unraveling a complex interplay (145-148). Dordrecht, The Netherlands: Springer.

Hayler, M. (2010). Telling tales out of school: self-narrative and the pedagogy of teacher education. In: Erickson, L. B., Young, J. R. \& Pinnegar, S. (Eds.), Negotiating the diverse 
landscape of teacher education (pp. 109-112). Herstmonceux Castle, East Sussex, England. Provo, Utah: Brigham Young University.

Hoban, G. (2007, April). Creating a self-study group. Paper presented at the annual conference of the American Educational Research Association, Chicago, IL.

Huxtable, M. \& Whitehead, J. (2016). How do we improve our contribution to the professional development of educational practitioners by enacting a self-study methodology? In Garbett, D. \& Ovens, A. (Eds.), Self-study of teacher education practices: Enacting self-study as methodology for professional inquiry (pp. 45-52). Herstmonceux Castle, East Sussex, England.

Huxtable, M. \& Whitehead, J. (2017). Enhancing professionalism in education through inquiry learing: a living theory research approach. In Boyd, P. \& Szplit, A. (Eds.) Teachers and teacher educators learning through inquiry: international perspectives (pp.99-122). Kieice-Krakow: Wydawnictwo. Attyka.

Info-TED (2016). The professional developmental needs of higher education-based teacher educators: an international comparative needs analysis. Presentation Brussels, June 2016.

Jackson, A. \& Burch, J. (2016). School Direct, a policy for initial teacher training in England: plotting a principled pedagogical path through a changing landscape. Professional Development in Education, 42, 511-526.

Jarvis, J. \& Burchell, H. (2006). Moving Toward Dialogue in Self-Study. In Fitzgerald, L. M., Heston, M. L. \& Tidwell, D. L., (Eds.), The Sixth international conference on self-study of teacher education practices. Collaboration and community: Pushing boundaries through self-study (135-137). Herstmonceux Castle, East Sussex, England. Cedar Falls, lowa: University of Northern lowa.

Jess, M., Atencio, M., \& Carse, N. (2016). The developmental Physical Education group: An emergent collaborative self-study. In Garbett, D., \& Ovens, A. (Eds.). Enacting self-study as methodology (101-107). Auckland, New Zealand: University of Auckland.

Jónsdóttir, S. R., Guđjónsdóttir, H., \& Gísladóttir, K. R. (2015). Using self-study to develop a third space for collaborative supervision of master's projects in teacher education. Studying Teacher Education 1(11), 32-48.

Jónsdóttir, S. \& Gísladóttir, K. (2016). Strengthening teacher identity through development of professional working theory. In Garbett, D., \& Ovens, A. (Eds.), Enacting self-study as methodology (pp. 449-454). Auckland, New Zealand: University of Auckland.

Jordan-Daus, K. (2016). Leadership and on finding my way through self-study. In Garbett, D. \& Ovens, A. (Eds.), Self-study of teacher education practices: Enacting self-study as methodology for professional inquiry (197-206). Herstmonceux Castle, East Sussex, England.

Kools, Q. (2017). Learning about inquiry. See: http://info-ted.eu/learning-about-inquiry/

Kools, Q. (2018) Topics studied in a self-study group. See: http://info-ted.eu/topics-studied-in-aself-study-group/

Koster, B., \& Dengerink, J. (2001). Towards a professional standard for Dutch teacher educators. European Journal of Teacher Education, 24(3), 343-354. DOI: 10.1080/02619760220128897

Koster, B., \& Van den Berg, B. (2014). Increasing professional self-understanding: Self-Study research by teachers with the help of biography, core reflection and dialogue. Studying Teacher Education, 10(1), 86-100.

Kristinsdóttir, J. V. (2010). Rethinking mathematics teaching in a community of inquiry. In L.B. Erickson, J.R. Young \& S. Pinnegar (Eds.), Navigating the public and private: negotiating the divers landscape of teacher education (pp. 125-128). Utah: Provo. 
Kristinsdóttir, J. V. (2016). Collaborative inquiry into mathematics teaching: Developing a partnership in researching practice in primary grades and teacher education. Dissertation. Reykjavík: University of Iceland.

LaBoskey, V. K. (2004). The methodology of self-study and its theoretical underpinnings. In J. J. Loughran, M. L. Hamilton, V. K. LaBoskey, \& T. Russell (Eds.), International handbook of selfstudy of teaching and teacher education practices (Vol. 2, pp. 817-869). Dordrecht: Kluwer.

Loughran, J. (2004). History and context of self-study of teaching. In Loughran, J., Hamilton, M.L., LaBoskey, V., \& Russell, T. (Eds.) (2004). International handbook of self-study of teaching and teacher education practices (pp. 7-39). Dordrecht/Boston: Kluwer Academic Publishers.

Loughran, J. (2006). Developing a pedagogy of teacher education: understanding teaching and learning about teaching. London: Routledge.

Loughran, J., \& Northfield, J. R. (1998). A framework for the development of self-study practice. In M. L. Hamilton (Ed.), Reconceptualizing teaching practice (pp. 7-18). London: Falmer Press.

Loughran, J., Hamilton, M.L., LaBoskey, V., \& Russell, T. (Eds.) (2004). International handbook of self-study of teaching and teacher education practices. Dordrecht/Boston: Kluwer Academic Publishers.

Loughran, J. (2008). "Seeking knowledge for teaching teaching: Moving beyond stories". In Fitzgerald, L.M., Heston, M.L. and Tidwell, D.L. (Eds), Pathways to change in teacher education: Dialogue, diversity and self-study. Proceedings of the Seventh International Conference on Self-Study of Teacher Education Practices, (pp. 218-221). Cedar Falls, IA: University of Northern lowa.

Loughran, J. (2014). Professionally Developing as a Teacher Educator. Journal of Teacher Education, 65(4), 271-283.

Lunenberg, M., Loughran, J., Schildkamp, K., \& Beishuizen, J. (2006). Self-study in a community of learning researchers: what can we do to support teachers and teacher educators to benefit from our research? In L.M. Fitzgerard, M.L. Heston, D.L. Tidwell (Eds.), Collaboration and community: Pushing boundaries through self-study (pp. 178-181). Ceder Falls: University of Northern lowa.

Lunenberg, M.L., Ponte, P. \& Ven, P-H. (2007). Why shouldn't teachers and teacher educators conduct research on their own practices? European Educational Research Journal, 6(1), 1324.

Lunenberg, M. \& Samaras, A.(2011). Developing a pedagogy for teaching self-study research: Lessons learned across the Atlantic. Teaching and Teacher Education, 27(5), 841-850.

Lunenberg, M.L., Korthagen, F. \& Zwart, R.C. (2010a). Critical issues in supporting self-study. Teaching and Teacher Education, 26(6), 1280-1289.

Lunenberg, M.L., Korthagen, F. \& Zwart, R.C. (2010b). Learning and working in a research community: A multi-layered self-study. In L.B. Erickson, J.R. Young \& S. Pinnegar (Eds.), Navigating the public and private: Negotiating the divers landscape of teacher education (pp. 137-140). Utah: Provo.

Lunenberg, M.L., Korthagen, F.A.J. \& Zwart, R.C. (2011). Self-study research and the development of a teacher educator's identity. European Educational Research Journal, 10(3), 407-420.

Lunenberg, M., Van den Bos, P., De Heer, A., Geursen, J., Hoekstra, W., Korthagen, F., Meindersma, Y., Morshuis, J., Rentrop, J., Ruit, J., Zwart, R. (2012). Learning about research; acting as a researcher. Experiences from our self-study community. In L.B. Erickson, J.R. Young, \& S. Pinnegar (Eds.), Extending inquiry communities: Illuminating teacher education through self-study (pp.187-190). Provo, Utah: Brigham Young University. 
Lunenberg, M., Dengerink, J., \& Korthagen, F. (2014). The professional teacher educator. Roles, behaviour, and professional development of teacher educators. Rotterdam/Boston/Taipei: Sense Publishers.

Lunenberg, M., Murray, J., Smith, K., \& Vanderlinde, R. (2017). Collaborative teacher educator professional development in Europe: different voices, one goal. Professional Development in Education, 43 (4), 556-572, DOI: 10.1080/19415257.2016.1206032

Lunenberg, M., Berry, A., Van den Bos, P., Geursen, J., Hagebeuk, E., De Heer, A., Radstake, J., Van Rijswijk, M., \& Tuithof, H. (2018). Signposts, Profits and Pitfalls in Teaching and Learning Selfstudy Research: a Conversation. In J. Ritter, M. Lunenberg, K. Pithouse-Morgan, A. Samaras, \& E, Vanassche (Eds), Teaching, learning, and enacting of self-study methodology: Unraveling a Complex Interplay (163-172). Dordrecht, The Netherlands: Springer.

Lyons, N., Halton, C., \& Freidus, H. (2012). Extending inquiry into learning over time across professions: promoting teaching and learning within a self-study. In L.B. Erickson, J.R. Young, \& S. Pinnegar (Eds.), Extending inquiry communities: Illuminating teacher education through self-study (pp.191-194). Provo, Utah: Brigham Young University.

Lyons, N., Halton, C., \& Freidus, H. (2013). Reflective inquiry as transformative self-study for professional education and learning. Studying Teacher Education, 9(2), 163-174.

MacPhail, A. (2017). 'Physical education and sport pedagogy' and the three 'A's: apprenticeship, academia and administration. Sport, Education and Society, 22(5), 669-683.

MacPhail, A. (2014). Becoming a teacher educator: Legitimate participation and the reflexivity of being situated. In Ovens, A., \& Fletcher, T. (Eds.) Self-study in physical education teacher education: Exploring the interplay between scholarship and practice (pp. 47-62). London, UK: Springer.

MacPhail, A., Patton, K., Parker, M. \& Tannehill, D. (2014). Leading by example: Teacher educators' professional learning through communities of practice. Quest, 66(1), 39-56.

MacPhail, A. (2011) Professional learning as a physical education teacher educator. Physical Education and Sport Pedagogy, 16(4), 435-445.

McNamara, O., Murray, J. \& Phillips, R. (2017). Policy and research evidence in the 'reform' of primary initial teacher education in England. Available: http://cprtrust.org.uk/wpcontent/uploads/2017/01/McNamara-report-170127.pdf [Accessed 06 February 2017].

McNiff, J. (2013). Action research: principles and practic. Abingdon: Routledge.

Murray, J., Czerniawski, G. \& Barber, P. (2011). Teacher educators' identities and work in England at the beginning of the second decade of the twenty-first century. Journal of Education for Teaching, 37, 261-277.

Ni Chroinin, D. Fletcher, T. and O'Sullivan, M. (2015) 'Using self-study to explore the processes of pedagogical innovation in physical education teacher education'. Asia-Pacific Journal of Health, Sport and Physical Education, 6(3), 273-286

Ní Chróinín, D., Fletcher, T. \& O’Sullivan, M. (2017). Pedagogical principles of learning to teach meaningful physical education. Physical Education and Sport Pedagogy. Download at http://dx.doi.org/10.1080/17408989.2017.1342789

Ní Chróinín, D., O’Sullivan, M. \& Fletcher, T. (2016). Critical friendship and meta-critical friendship: Reinterogating assumptions. In K. Ragoonaden \& S. Bullock (Eds.). Mindfulness and critical friendship (pp. 77-90). London. Lexington Books.

O'Sullivan, M. (2014). Where we go from here: Developing pedagogies for PETE and the use of self-study in physical education and teacher education. In Ovens, A., \& Fletcher, T. (Eds.), Self-study in physical education teacher education: Exploring the interplay between scholarship and practice (pp.169-180). London, UK: Springer. 
Óskarsdóttir, E. (2017). Constructing support as inclusive practice: A self-study. Dissertation. Reykjavík: University of Iceland.

Parker, M., NíChróinín, D., Coulter, M., Walsh, C., \& McFlynn, P. (2016) 'Snapshots: Teacher educator professional learning shaping teacher educator practices' In Garbett, D. \& Ovens, A. (Eds.), Self-study of teacher education practices: Enacting self-study as methodology for professional inquiry (p.189). Herstmonceux, UK: Self-Study of Teacher Education Practices (SSTEP).

Philpott, C. (2014). Theories of professional learning, Northwich: Critical Publishing.

Pinnegar, S. \& Hamilton, M. L. (2010). Self-study of practice as a genre of qualitative research: Theory, methodology and practice. Dordrecht: Springer.

Pithouse-Morgan, K., Muthukrishna, N., Pillay, D., Van Laren, L., Chisanga, T., Meyiwa, T., et al. (2015). Learning about co-flexivity in a transdisciplinary self-study research supervision community. In K. Pithouse-Morgan \& A. P. Samaras (Eds.), Polyvocal professional learning through self-study research (pp. 145-171). Rotterdam: Sense Publishers.

Radstake, J. (2018). Stimulating student growth through written feedback: A self-study on supporting students' research projects. In J. Ritter, M. Lunenberg, K. Pithouse-Morgan, A, Samaras, \& E, Vanassche (Eds.), Teaching, learning, and enacting of self-study methodology: Unraveling a complex interplay (pp.131-144). Dordrecht, The Netherlands: Springer.

Ritter, J., Lunenberg, M., Pithouse-Morgan, K., Samaras, A., \& Vanassche, E. (Eds.) (2018). Teaching, learning, and enacting of self-study methodology: Unraveling a complex interplay. Dordrecht, The Netherlands: Springer.

Russell, T. \& Loughran, J. (eds.) (2007). Enacting a pedagogy of teacher education. Values, relationships and practices. Abingdon: Routledge.

Samaras, A., \& Freese, A. (2006). Self-study of teaching practices. New York: Peter Lang.

Samaras, A. P., Adams-Legge, M., Breslin, D., Mittapalli, K., Magaha O'Looney, J., \& Wilcox, D. R. (2008). Collective creativity: A learning community of self-study scholars. In A. P. Samaras, A. R. Freese, C. Kosnik, \& C. Beck (Eds.), Learning communities in practice (pp. 141-155). Dordrecht, The Netherlands: Springer.

Samaras, A., Guđjónsdóttir, H., McMurrer, J. R. \& Dalmau, M. D. (2012). Self-study of a professional organization in pursuit of a shared enterprise. Studying Teacher Education: $A$ Journal of Self-study of Teacher Education Practice, 8(3), 303-320.

Samaras, A. \& Lunenberg, M.L. (2010). Dialoguing About Our Teaching of Self-study: A CrossAtlantic collaborative study. In L.B. Erickson, J.R. Young \& S. Pinnegar (Eds.), Navigating the Public and Private: Negotiating the Divers Landscape of Teacher Education (pp. 240-244). Provo, Utah: Brigham Young University.

Schon, D. A. (1987). Educating the reflective practitioner. London: Jossey-Bass.

Schratz, M. (2014). The European teacher: transnational perspectives in teacher education policy and practice. CEPS journal. 4, 11-17.

Smith, K. (2017): Learning from the past to shape the future. European Journal of Teacher Education, DOI: 10.1080/02619768.2017.1385058

Svojanovsky, P. \& Nehyba, J. (2016). Teaching teacher educators: A self-study of our learning from experience. In Garbett D., Ovens A.P. (Eds.), Enacting self-study as methodology for professional inquiry (pp. 249-256). Auckland, New Zealand: University of Auckland.

Tack, H. (2017). Towards a better understanding of teacher educators' professional development: Theoretical and empirical insight into their researcherly disposition. Ph.D. Dissertation Ghent University. 
Tack, H., \& Vanderlinde, R. (2014). Teacher educators' professional development: Towards a typology of teacher educators' researcherly disposition. British Journal of Educational Studies, (62)3, 297-315.

Tannehill, D., Parker, M., Tindall, D., Moody, B. \& MacPhail, A. (2016) Looking across and within: studying ourselves as teacher educators. Asia-Pacific Journal of Health, Sport and Physical Education, 6(3), 299-311.

Tannehill, D. (2014). My journey to become a teacher educator. Physical Education and Sport Pedagogy, 21(1), 105-120.

Thomas L., \& Geursen J.W. (2016), Relinquishing and renegotiating control in an undergraduate methods course to improve engagement and learning. In Garbett D., Ovens A.P. (Eds.), Enacting self-study as methodology for professional inquiry (pp. 403-410). Auckland, New Zealand: University of Auckland.

Thomas, L., \& Geursen, J. (2013). Creating spaces for reflections on learning to teach a foreign language through open journals: A Canadian-Dutch self-study. Studying Teacher Education, 9(1), 18-30.

Ulvik, M. (2014). Student-teachers doing action research in their practicum: why and how?, Educational Action Research, DOI: 10.1080/09650792.2014.918901

Vanassche, E. (2014). (Re)Constructing teacher educators' professionalism: Biography, workplace and pedagogy. Leuven: Faculty of Psychology and Educational Sciences.

Vanassche, E., \& Kelchtermans, G. (2015). Facilitating self-study of teacher education practices: Toward a pedagogy of teacher educator professional development. Professional Development in Education, 42(1), 100-122. doi:10.1080/19415257.2014.986813

Vázquez, D. (2014). Reflections on tutoring ancient Greek philosophy: A case study of teaching first-year undergraduates in the UK. Studying Teacher Education, 10, 117-129.

White, E. (2011). Working towards explicit modelling: Experiences of a new teacher educator. Professional Development in Education, 37, 483-497.

Whitehead, J. (1993). The Growth of educational knowledge: Creating your own living educational theories. Bournemouth: Hyde.

Whitehead, J. (2008). Living theories of educational influences in teacher education with dialogue, diversity and self-study. In Heston, M. L., Tidwell, D. L., East, K. K. \& Fitzgerald, L. M. (Eds.), Pathways to change in teacher education: Dialogue, diversity and self-study (pp. 308-312). Herstmonceux Castle, East Sussex, England. Cedar Falss, lowa: University of Northern lowa.

Whitehead, J. \& Huxtable, M. (2008). The Catalytic validity of the living educational theories of self-study researchers in improving practice and in creating a new epistemology of educational knowledge. In Heston, M. L., Tidwell, D. L., East, K. K. \& Fitzgerald, L. M. (Eds.), Pathways to change in teacher education: Dialogue, diversity and self-study. (pp. 313-317). Herstmonceux Castle, East Sussex, England. Cedar Falls, lowa: University of Northern lowa.

Whitehead, J. \& Huxtable, M. (2010). Educational knowledge and forms of accountability within the complex ecologies of self-study. In Erickson, L. B., Young, J. R. \& Pinnegar, S., (Eds.), The eighth international conference on self-study of teacher education practices. Navigating the public and private: Negotiating the diverse landscape of teacher education (pp. 277-281). Herstmonceux Castle, East Sussex, England. Provo, Utah: Brigham Young University,

Whitehead, J. 2014. A self-study contribution to a history of the self-study of teacher education practices. In Garbett, D. \& Ovens, A. (Eds.), Changing practices for changing times: Past, present and future possibilities for self-study research. (pp. 204-207). Herstmonceux Castle, East Sussex, England.

Whitehead, J. \& Huxtable, M. (2014). Generating living-educational-theories from changing practices for changing times: Past, present and future possibilities of self-study research. In 
Garbett, D. \& Ovens, A. (Eds.), Changing practices for changing times: Past, present and future possibilities for self-study research. (pp. 208-211). Herstmonceux Castle, East Sussex, England.

Williams, J. \& Hayler, M. P. (2016). Professional learning from the process of co-editing journeys of becoming. In Garbett, D. \& Ovens, A. (Eds.), Self-study of teacher education practices: Enacting self-study as methodology for professional inquiry (pp. 147-154). Herstmonceux Castle, East Sussex, England.

Wilson, V., Jordan-Daus, K. \& Vincent, K. (2014). Through the looking glass: Three perspectives on establishing a collaborative self-study group. In Garbett, D. \& Ovens, A. (Eds.), Changing practices for changing times: Past, present and future possibilities for self-study research (pp. 215-217). Herstmonceux Castle, East Sussex, England.

Zwart, R.C., Geursen, J., Heer, A. de, Lunenberg, M.L. \& Korthagen, F. (2008). The importance of being aware: Work in progress by teacher educators and their student teachers. In M. Heston, D. Tidwell, K. East \& L. Fitzgerald (Eds.), Pathways to change in teacher education: dialog, diversity and self-study (pp. 328-332). Ceder Falls: University of Northern lowa. 